\title{
Life story books for people with dementia: a systematic review
}

\author{
Teuntje R. Elfrink, ${ }^{1}$ Sytse U. Zuidema, ${ }^{2}$ Miriam Kunz ${ }^{2}$ and Gerben J. Westerhof ${ }^{1}$ \\ ${ }^{1}$ Department of Psychology, Health and Technology, University of Twente, Enschede, the Netherlands \\ ${ }^{2}$ Department of General Practice and Elderly Care Medicine, University of Groningen, University Medical Center Groningen, Groningen, the Netherlands
}

\section{ABSTRACT}

Objectives: There is an increasing evidence that reminiscence therapy is effective in improving cognitive functions and reducing depressive symptoms in people with dementia. Life story books (LSBs) are frequently used as a reminiscence tool to support recollecting autobiographical memories. As little is known about how LSBs are used and what type of studies have been employed to evaluate LSB interventions, we conducted a systematic review.

Methods: The electronic databases Scopus, PubMed, and PsychINFO as well as reference lists of existing studies were searched to select eligible articles. Out of the 55 studies found, 14 met the inclusion criterion of an original empirical study on LSBs in people with dementia.

Results: The majority of the LSBs were tangible books, although some digital applications were also found. The LSBs were created mostly in individual sessions in nursing homes with a median of six sessions. Some studies only focused on the person with dementia, while others also examined (in)formal caregivers. Most studies used qualitative interviews, case studies, and/or (pilot) randomized controlled trial (RCTs) with small sample sizes. Qualitative findings showed the value of LSBs in triggering memories and in improving the relation with the person with dementia. Quantitative effects were found on, e.g. autobiographical memory and depression of persons with dementia, quality of relationship with informal caregivers, burden of informal caregivers, and on attitudes and knowledge of formal caregivers.

Conclusions: This systematic review confirms that the use of LSBs to support reminiscence and personcentered care is promising, but larger RCTs or implementation studies are needed to establish the effects of LSBs on people with dementia.

Key words: life story book, reminiscence, dementia, systematic review, person-centered care, caregivers

\section{Introduction}

In 2015, the number of people living with dementia worldwide was estimated at 46.8 million. This number is expected to increase to 74.7 million in 2030 and 131.5 million in 2050 (Prince et al., 2015). Dementia is often accompanied by neuropsychiatric symptoms (NPS). Dementia and the related NPS not only affect the quality of life of the person with dementia, but also result in a higher burden of informal caregivers and a lower quality of their lives (De Vugt et al., 2003; Peeters et al., 2012; Conde-Sala et al., 2016). Dementia often leads to disability and a high and expanding need for care and support of a caregiver (Prince et al.,

Correspondence should be addressed to: Teuntje R. Elfrink, MSc, Department of Psychology, Health and Technology, University of Twente, P.O. Box 217, 7500 AE Enschede, the Netherlands. Email: t.r.elfrink@utwente.nl. Received 5 Dec 2017; revision requested 5 Feb 2018; revised version received 7 Feb 2018; accepted 26 Feb 2018. First published online 18 July 2018.
2013). Overall, dementia is among the top five with the highest burden of disease for persons over 65 years and it belongs to the diseases with the highest burden for informal caregivers (McKeith and Cummings, 2005). This burden includes physical, emotional, and economic aspects (World Health Organization, 2017). Furthermore, dementia is one of the most costly diseases worldwide (Prince et al., 2015; World Health Organization, 2017).

Higgs and Gilleard (2017) plead for a shift to a more person-centered approach in dementia care: person-centered care (PCC). The shift from medical, routine-driven care to personalized, individualized care - regardless of the cognitive or functional capacity of the patients - is called 'the culture change" (Koren, 2010). In 2016, the American Geriatrics Society Expert Panel developed a summarizing definition of PCC: "Person-centered care" means that individuals' values and preferences are elicited and, once expressed, guide 
all aspects of their health care, supporting their realistic health and life goals. Person-centered care is achieved through a dynamic relationship among individuals, others who are important to them, and all relevant providers. This collaboration informs decision-making to the extent that the individual desires (AGS, 2016).

PCC can be enhanced by using a person's biography and memories (Clarke, 2000; Clarke et al., 2003). The use of written or oral life histories to improve psychological well-being is described as reminiscence and is often used with people with dementia (McKeown et al., 2006; VandenBos, 2006). Several (systematic) reviews have shown that reminiscence activities can contribute to the mental health and quality of life of persons with dementia (Woods et al., 2005; Subramaniam and Woods, 2012; Blake, 2013). A recent metaanalysis of Huang and colleagues (2015) concluded that reminiscence therapy has a small effect on improving cognitive functioning and a moderate effect on reducing depressive symptoms in older persons with dementia, predominantly for those living in institutions.

The creation of a life story book (LSB) is a common approach in reminiscence (McKeown et al., 2006). The use of LSBs with personal memories that are constructed together with the person with dementia is especially promising (Subramaniam and Woods, 2012). Besides the recollection of personal memories, receiving a tangible output in the form of a LSB is highly valued by patients (Morgan and Woods, 2010). In recent years, LSBs are used for multiple purposes and in multiple settings, while studies that evaluate LSB interventions for people with dementia are emerging. To provide an overview of how LSBs are used and what is known from research, we conducted a systematic review with two guiding questions:

1. How are LSBs used in dementia care?

2. What are the designs and findings of studies on the use of LSBs?

\section{Methods}

This systematic review was conducted according to the preferred reporting items for systematic reviews and meta-analyses statement (Moher et al., 2015).

\section{Inclusion and exclusion criteria}

Population

This review concerns people with mild cognitive impairment (MCI) or dementia.
TYPES OF INTERVENTIONS

Interventions that use LSBs were eligible for inclusion. There had to be a clear description of the LSB, and the LSB had to contain not only biographical facts but also autobiographical elements or memories.

\section{OUTCOMES OF INTEREST}

The outcomes of interest were (1) the use of LSBs and (2) the designs and findings of qualitative and quantitative studies on their use.

\section{TYPES OF EVIDENCE}

In order to answer the two research questions, all empirical study designs were considered. Academic peer reviewed full-text papers published in printed or electronic format in academic journals or conference proceedings were deemed eligible for inclusion. No language restrictions were applied. Theses, book chapters, non-empirical studies, or unpublished work were excluded.

\section{Data sources and search strategy}

Academic databases Scopus, PubMed, and PsycINFO were searched. Additional sources included reference lists of relevant articles and reviews and expert consultation. In the search, strategy terms on "LSB" were combined with terms on dementia. All following terms were being searched in titles, abstracts, and keywords: "life story book" or "life story album" or "storybook" or "life album" or "memory book" or "memory album" or "reminiscence book" or "reminiscence album" or "biography book" or "autobiography book" or "life history book" AND "dementia" or "Alzheimers" or "mci" or "mild cognitive impairment". Two authors (TE and GW) performed the last search run on October 19, 2017.

\section{Study selection}

The flow diagram of the search and selection procedure of studies is illustrated in Figure 1. Two data extractors (TE and GW) assessed the eligibility independently in a standardized manner. The 55 retrieved records from the search were screened by title and abstract. An interrater reliability check on the 55 articles was performed, resulting in an agreement of $98 \%$ and a Cohen's $\kappa$ of 0.96 , which is considered as 'almost perfect"' (McHugh, 2012). The disagreement was resolved by consensus, in this case by excluding the article (since no LSBs were used in the intervention). After this first screening, a total of 33 full articles were assessed for eligibility. The extractors read these 33 articles independently. For this second round, the agreement was $91 \%$, with a Cohen's $\kappa$ of 0.82 , which is considered as the upper bound of "strong." The remaining 


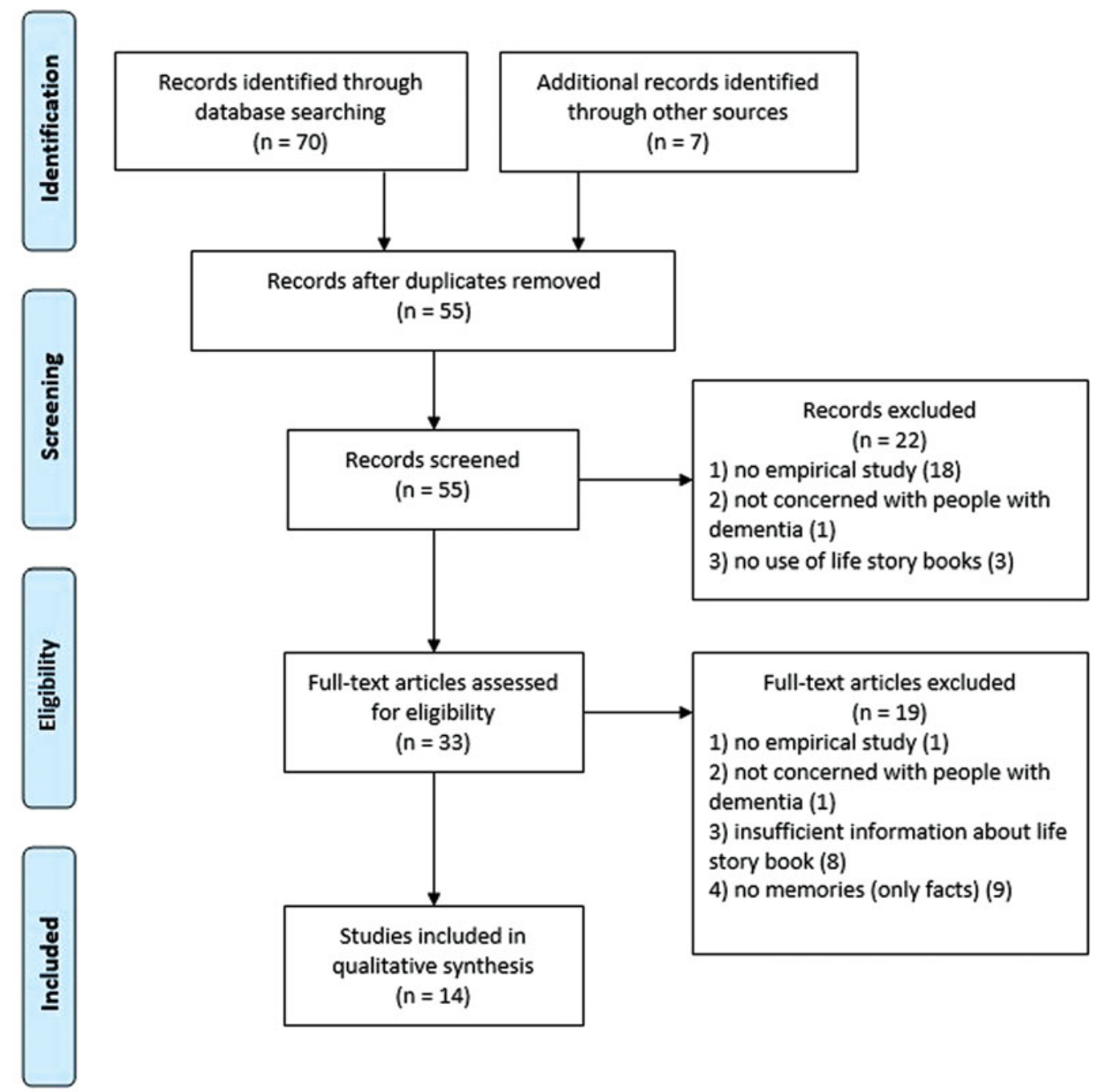

Figure 1. Flow diagram of the search and selection procedure of studies.

three discrepancies were resolved by consensus to exclude the articles (based on the third criterion of insufficient information about the LSB).

\section{Data extraction}

In order to answer the first research question How are LSBs used in dementia care? the following information was extracted from the articles: target group; type and characteristics of the LSB; implementation of the LSB; and time to create the LSB. To answer the second research question What are the findings of studies on the use of LSBs? the following factors were extracted: aim of the study; type of study; sample size; instruments and/or outcome variables; and findings.

\section{Results}

\section{Study identification and selection}

Figure 1 summarizes the databases hits, exclusion, and final inclusion in a flow diagram. A total of
70 records were found from Scopus (34), PubMed (22), and PsycINFO (14). Reference lists searches and expert consultation added seven studies. After removing duplicates, 55 studies remained and were screened for title and abstract. Based on title and abstract, 22 were discarded as the studies did not meet the inclusion criteria. The full texts of the remaining 33 studies were assessed for eligibility. Of these 33, 19 studies did not meet the inclusion criteria. Finally, a total of 14 studies met the inclusion criteria and were included in the systematic review. Out of the 14 included studies, 12 were identified through database searching.

\section{Study characteristics}

All 14 studies were empirical studies published in peer-reviewed journals or conference proceedings. The studies were published between 2003 and 2017. Ten of the 14 studies were conducted in the last five years between 2013 and 2017. In total, 243 persons with dementia participated in the studies. 


\section{Research question 1: How are life story books used in dementia care?}

To answer this question, first, a general description of the different target groups and type and characteristics of the LSBs are presented in Table 1 . Second, Table 2 shows descriptions of the implementation processes and the time needed to create a LSB.

\section{Target group}

All included studies concerned people with dementia: Ten studies concerned people with mild to moderate dementia, one study very mild to mild, one mild to severe, one different stages, and one severe dementia. In the study of Crook et al. (2016), the participants suffered from mild to moderate dementia and had Down syndrome. A total of nine LSB interventions were carried out for individuals, whereas the other five were dyadic interventions. The mean age varied between 58.6 (Crook et al., 2016) and 92.8 years (Andrews-Salvia et al., 2003). Eleven studies involved both men and women, three only women. The countries in which the studies took place where North Wales (two), United States (solely four; combined with Japan one), United Kingdom (three), Malaysia (two), Korea (one), and Northern Ireland (one). A majority of eight studies was performed in a care home setting, whereas three studies took place at the home situation and two studies in both settings. In one study (Hashim et al., 2013), the setting was not clear.

\section{Type and characteristics of the life story books}

In eight studies, a tangible LSB was created. In three studies, both a traditional and another type of LSB was formed, namely a digital book (IngersollDayton et al., 2016), a rummage box (Crook et al., 2016), and a pen picture (McKeown et al., 2013). In three studies, only a digital version was created: both studies by Hashim et al. $(2013 ; 2015)$ worked with a digital application and the study of Subramaniam and Woods (2016) used previously constructed tangible LSBs as input to create a digital life story movie. A wide variation of materials was used to create the LSBs: photographs, music, narration, stories, blank pages, quotations, and news items. The order of the stories told in the LSBs, when known, was chronological. The length of the books varied from 2 pages (the pen picture) to 70 pages (Subramaniam et al., 2014). The average length of the movies of the Subramaniam and Woods (2016) study was 18 minutes.

\section{Implementation of the life story books}

Both the participant and a partner or relative were involved in the process of creating the LSB in five studies. A professional caregiver was additionally helping in five cases. The participant created the book with the professional caregiver - so without a relative - in two cases and in the two remaining cases, it was the other way around: the participant was not involved in the process and the book was created by the relative and a professional caregiver. The researcher helped creating the LSB in the study of Andrews-Salvia et al. (2003) and in the control condition of the Subramaniam and Woods study. In five studies, Haight's life review model or life review experience form (LREF; Haight, 1992) was used in the sessions to create the LSB. A total of four studies used the couples life story approach (once combined with techniques from Haight). The number of sessions involved in creating a LSB varied from 3 (Subramaniam and Woods, 2016) to 16 (Subramaniam et al., 2014) with a median of six sessions, while the amount of weeks it took ranged from 9 days (Crook et al., 2016) to 12 weeks (Morgan and Woods, 2010; Subramaniam et al., 2014) and the time per session variated between 15 minutes (Hashim et al., 2015) and 120 minutes (Ingersoll-Dayton et al., 2013). No information was found about actual use, e.g. whether it has been used daily or weekly, for how long, and by whom, of the LSBs after the process of creating it.

\section{Research question 2: What are the designs and findings of studies on the use of life story books?}

To answer this question, the main characteristics of the study designs (aims, types of studies, and sample sizes) are presented in Table 3. Table 4 shows the instruments and/or outcome variables used in the studies and presents the findings (qualitative and/or quantitative) of the different studies.

\section{Aim of study}

The aims of the studies can be divided into two main categories: (1) getting insight in the challenges and possibilities of implementing LSB interventions in dementia care by evaluating the process and (2) gaining (initial) evidence on the effectiveness of the LSB interventions on participants (e.g. on autobiographical memory and quality of life and mood) and/or their (in)formal caregivers (e.g. on relationship and burden). Seven studies focused on the first aim, three on the second aim, and four had a combination of both aims. 
Table 1. Overview of target group and type and characteristics of the life story book.

\begin{tabular}{|c|c|c|c|c|c|c|c|c|c|c|}
\hline \multirow[b]{2}{*}{ AUTHOR } & \multicolumn{6}{|c|}{ TARGET GROUP } & \multicolumn{2}{|c|}{ TYPE AND CHARACTERISTICS } & \multicolumn{2}{|c|}{ OF THE LIFE STORY BOOK } \\
\hline & $\begin{array}{c}\text { CONDITION } \\
\text { OF } \\
\text { DEMENTIA }\end{array}$ & $\begin{array}{l}\text { INDIVIDUAL } \\
\text { OR DYADIC }\end{array}$ & $\begin{array}{l}\text { MEAN } \\
\text { AGE }\end{array}$ & GENDER & COUNTRY & $\begin{array}{l}\text { LIVING } \\
\text { SITU- } \\
\text { ATION }\end{array}$ & $\begin{array}{l}\text { TYPE OF } \\
\text { LSB }\end{array}$ & $\begin{array}{l}\text { MATERIALS } \\
\text { USED }\end{array}$ & $\begin{array}{l}\text { ORDER OF } \\
\text { MEMORIES }\end{array}$ & $\begin{array}{c}\text { PAGES/NO } \\
\text { OF } \\
\text { MEMORIES }\end{array}$ \\
\hline Kwak et al. (2018) & $\begin{array}{l}\text { Very mild to } \\
\text { mild }\end{array}$ & Dyadic & 76.5 & $\mathrm{M}+\mathrm{F}$ & $\begin{array}{l}\text { South } \\
\text { Korea }\end{array}$ & $\begin{array}{l}\text { Home and } \\
\text { care } \\
\text { home }\end{array}$ & Book & Unknown & Unknown & Unknown \\
\hline $\begin{array}{l}\text { Subramaniam and } \\
\text { Woods (2016) }\end{array}$ & $\begin{array}{l}\text { Mild to } \\
\text { moderate }\end{array}$ & Individual & 82 & $\mathrm{M}+\mathrm{F}$ & $\begin{array}{l}\text { North } \\
\text { Wales }\end{array}$ & Care home & Movie & $\begin{array}{l}\text { Photographs and } \\
\text { other visual } \\
\text { materials } \\
\text { augmented with } \\
\text { background } \\
\text { music, favorite } \\
\text { songs, and } \\
\text { narration }\end{array}$ & $\begin{array}{l}\text { Chronological } \\
\text { with division } \\
\text { in six } \\
\text { segments }\end{array}$ & $\begin{array}{l}\text { Average } \\
\text { length: } 18 \\
\text { minutes }\end{array}$ \\
\hline $\begin{array}{l}\text { Ingersoll-Dayton } \\
\text { et al. (2016) }\end{array}$ & $\begin{array}{l}\text { Mild to } \\
\text { moderate }\end{array}$ & Dyadic & $\begin{array}{l}74(\mathrm{US}) \\
77.4(\mathrm{~J})\end{array}$ & $\mathrm{M}+\mathrm{F}$ & $\begin{array}{l}\text { United } \\
\text { States } \\
\text { and Japan }\end{array}$ & Home & $\begin{array}{l}\text { Traditional } \\
\text { (US) and } \\
\text { digital } \\
\text { book }(\mathrm{J})\end{array}$ & $\begin{array}{l}\text { Photos, stories, } \\
\text { and blank pages } \\
\text { for the future }\end{array}$ & Chronological & Unknown \\
\hline $\begin{array}{l}\text { Crook et al. } \\
\quad(2016)\end{array}$ & $\begin{array}{l}\text { Mild to } \\
\text { moderate } \\
\text { and Down } \\
\text { syndrome }\end{array}$ & Individual & 58.6 & $\mathrm{M}+\mathrm{F}$ & $\begin{array}{l}\text { United } \\
\text { Kingdom }\end{array}$ & Care home & $\begin{array}{l}\text { Book and } \\
\text { rummage } \\
\text { box }\end{array}$ & $\begin{array}{l}\text { Photographs and } \\
\text { memorabilia }\end{array}$ & Unknown & Unknown \\
\hline $\begin{array}{l}\text { Hashim et al. } \\
\text { (2015) }\end{array}$ & $\begin{array}{l}\text { Mild form of } \\
\text { AD }\end{array}$ & Individual & 74 & $\mathrm{~F}$ & Malaysia & $\begin{array}{l}\text { With } \\
\text { family }\end{array}$ & $\begin{array}{l}\text { Digital ap- } \\
\text { plication }\end{array}$ & $\begin{array}{l}\text { Pictures, details, } \\
\text { and voice of } \\
\text { family members } \\
\text { and } \\
\text { photographs } \\
\text { and } \\
\text { descriptions of } \\
\text { past events }\end{array}$ & Unknown & Unknown \\
\hline $\begin{array}{r}\text { Subramaniam } \\
\text { et al. }(2014)\end{array}$ & $\begin{array}{l}\text { Mild to } \\
\text { moderate }\end{array}$ & Individual & 86 & $\mathrm{M}+\mathrm{F}$ & $\begin{array}{l}\text { North } \\
\text { Wales }\end{array}$ & Care home & Book & $\begin{array}{r}\text { Pictures and } \\
\text { quotations }\end{array}$ & Chronological & $\begin{array}{l}50-70 \\
\text { pages }\end{array}$ \\
\hline $\begin{array}{l}\text { Scherrer et al. } \\
\text { (2014) }\end{array}$ & $\begin{array}{l}\text { Mild to } \\
\text { moderate }\end{array}$ & Dyadic & 74 & $\mathrm{M}+\mathrm{F}$ & $\begin{array}{l}\text { United } \\
\text { States }\end{array}$ & Home & Book & $\begin{array}{l}\text { Photographs, } \\
\text { cards, news } \\
\text { items, and } \\
\text { blank pages for } \\
\text { the future }\end{array}$ & $\begin{array}{l}\text { Chronological } \\
\text { (assumed) }\end{array}$ & Unknown \\
\hline
\end{tabular}




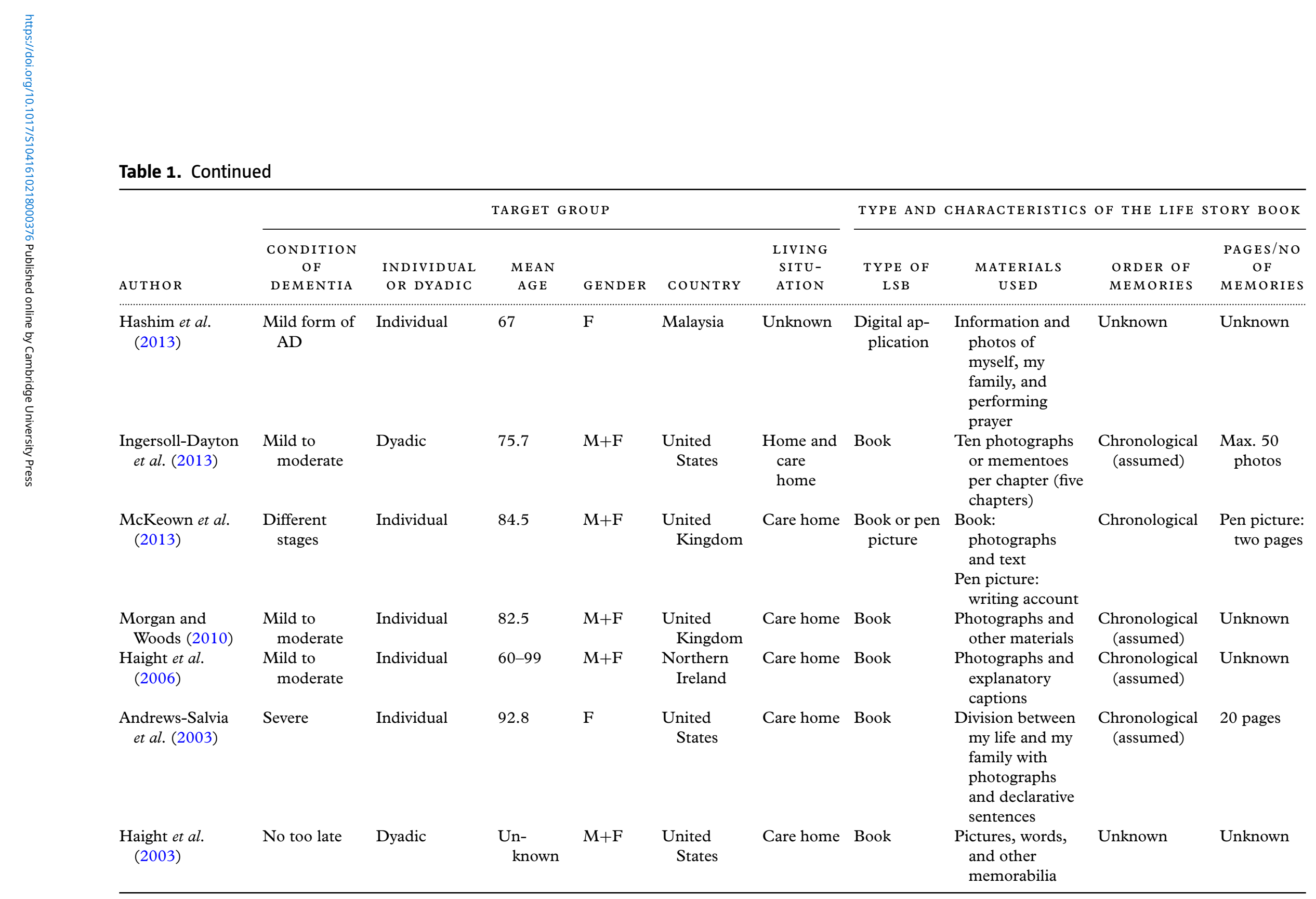


Table 2. Description of the implementation and the time needed to create a life story book

\begin{tabular}{|c|c|c|c|c|}
\hline \multirow[b]{2}{*}{ AUTHOR } & \multicolumn{3}{|c|}{ IMPLEMENTATION OF LIFE STORY BOOK } & \multirow[b]{2}{*}{ TIME TO CREATE } \\
\hline & THOSE INVOLVED & ROLE OF RESEARCHER(S) & APPROACH & \\
\hline Kwak et al. (2018) & Participant and partner & $\begin{array}{l}\text { Engaging participant in process } \\
\text { and compiling the book }\end{array}$ & $\begin{array}{l}\text { The couples life story approach } \\
\text { which makes use of life review } \\
\text { techniques from Haight (1992) }\end{array}$ & Five weekly sessions \\
\hline $\begin{array}{l}\text { Subramaniam and } \\
\text { Woods (2016) }\end{array}$ & Participant and relative & Co-editor of the movie & $\begin{array}{l}\text { The life story movie is based on a } \\
\text { previously completed } \\
\text { conventional book }\end{array}$ & $\begin{array}{l}\text { Creation of movie: on average } 8.3 \\
\text { weeks } \\
\text { Test prototype: on average three } \\
\text { sessions }\end{array}$ \\
\hline $\begin{array}{l}\text { Ingersoll-Dayton } \\
\text { et al. (2016) }\end{array}$ & Participant and partner & Compiling the life story & The couples life story approach & Five weekly sessions \\
\hline Crook et al. (2016) & $\begin{array}{l}\text { Participant and family member } \\
\text { or other consultee }\end{array}$ & $\begin{array}{l}\text { Facilitating interaction and } \\
\text { delivering intervention }\end{array}$ & Unknown & Nine daily sessions of 30 minutes \\
\hline Hashim et al. (2015) & Participant and caretaker & $\begin{array}{l}\text { Explaining and demonstrating } \\
\text { the use of the application }\end{array}$ & Unknown & $\begin{array}{l}\text { Eight weekly sessions of 15-30 } \\
\text { minutes }\end{array}$ \\
\hline $\begin{array}{l}\text { Subramaniam et al. } \\
\text { (2014) }\end{array}$ & $\begin{array}{l}\text { Co-creation: participant and } \\
\text { therapist } \\
\text { Gift: relative and researcher }\end{array}$ & $\begin{array}{l}\text { Co-creation: therapist as } \\
\text { compiler } \\
\text { Gift: working close together with } \\
\text { relative }\end{array}$ & $\begin{array}{l}\text { Co-creation: based on Haight's } \\
\text { life review model and life } \\
\text { review experiencing form } \\
\text { (LREF; Haight, 1992) }\end{array}$ & $\begin{array}{l}\text { Co-creation: } 11-16 \text { sessions in } 12 \\
\text { weeks } \\
\text { Gift: } 5-6 \text { sessions in } 12 \text { weeks }\end{array}$ \\
\hline $\begin{array}{l}\text { Scherrer et al., } \\
\quad(2014)\end{array}$ & $\begin{array}{l}\text { Participant, partner, and social } \\
\text { worker }\end{array}$ & No role in the actual intervention & $\begin{array}{l}\text { The couples life story approach } \\
\text { with reminiscence sessions with } \\
\text { the social worker and the dyad }\end{array}$ & Five weekly sessions \\
\hline Hashim et al. (2013) & Participant, caretaker, and doctor & $\begin{array}{l}\text { Interviewing caretaker and } \\
\text { doctor in order to develop } \\
\text { content of the application }\end{array}$ & Unknown & $\begin{array}{l}\text { Test prototype: four sessions in } \\
\text { four weeks }\end{array}$ \\
\hline $\begin{array}{l}\text { Ingersoll-Dayton } \\
\text { et al. (2013) }\end{array}$ & $\begin{array}{l}\text { Participant, partner, and social } \\
\text { worker }\end{array}$ & No role in the actual intervention & $\begin{array}{l}\text { The couples life story approach } \\
\text { with reminiscence sessions with } \\
\text { the social worker and the dyad }\end{array}$ & $\begin{array}{l}\text { Five weekly sessions with an } \\
\text { average time span of } 76 \\
\text { minutes }(40-120) \text { per session }\end{array}$ \\
\hline $\begin{array}{l}\text { McKeown et al. } \\
\quad(2013)\end{array}$ & $\begin{array}{l}\text { Participant, multi-professional } \\
\text { staff, and/or family carers }\end{array}$ & $\begin{array}{l}\text { Facilitating the life story work } \\
\text { intervention }\end{array}$ & Life story work & Unknown \\
\hline $\begin{array}{l}\text { Morgan and Woods } \\
(2010)\end{array}$ & Participant and carer or relative & $\begin{array}{l}\text { Engaging participant in process } \\
\text { and compiling the book }\end{array}$ & $\begin{array}{l}\text { Haight's life review experiencing } \\
\text { form (LREF; Haight, 1992) }\end{array}$ & $\begin{array}{l}\text { Approximately } 12 \text { weekly sessions } \\
\text { of } 30-60 \text { minutes }\end{array}$ \\
\hline Haight et al. (2006) & $\begin{array}{l}\text { Participant and care staff (family } \\
\text { slightly) }\end{array}$ & No role in the actual intervention & $\begin{array}{l}\text { Haight's life review model and } \\
\text { life review experiencing form } \\
\text { (LREF; Haight, 1992) }\end{array}$ & Six weekly sessions of 60 minutes \\
\hline
\end{tabular}


Table 2. Continued

IMPLEMENTATION OF LIFE STORY BOOK

\begin{tabular}{|c|c|c|c|c|}
\hline AUTHOR & THOSE INVOLVED & $\begin{array}{c}\text { ROLE OF } \\
\text { RESEARCHER }(s)\end{array}$ & APPROACH & TIME TO CREATE \\
\hline $\begin{array}{l}\text { Andrews- } \\
\text { Salvia et al. } \\
\text { (2003) }\end{array}$ & $\begin{array}{l}\text { Family members and } \\
\text { researcher }\end{array}$ & $\begin{array}{l}\text { Compiling the book } \\
\text { together with family } \\
\text { members }\end{array}$ & Unknown & $\begin{array}{l}12 \text { sessions in three } \\
\text { weeks, varying from } \\
7.5 \text { to } 22.5 \text { minutes }\end{array}$ \\
\hline $\begin{array}{l}\text { Haight et al. } \\
\quad(2003)\end{array}$ & $\begin{array}{l}\text { Condition 1: both } \\
\text { caregiver and care } \\
\text { receiver participated } \\
\text { separately, but } \\
\text { simultaneously } \\
\text { Condition 2: only } \\
\text { caregiver (without } \\
\text { participant) }\end{array}$ & $\begin{array}{l}\text { Condition 1: two } \\
\text { reviewers visiting the } \\
\text { home } \\
\text { Condition 2: unknown }\end{array}$ & $\begin{array}{l}\text { Haight's life review model } \\
\text { and life review } \\
\text { experiencing form } \\
\text { (LREF; Haight, 1992) }\end{array}$ & $\begin{array}{l}\text { Six weekly sessions of } 60 \\
\text { minutes }\end{array}$ \\
\hline
\end{tabular}

Hence, there were 11 studies with the first aim and seven with the second aim in total.

\section{Type of study}

The 11 studies that evaluated the implementation process used a multiple qualitative case study (three), single case study (two), case-study vignette (three), or another qualitative approach (three). Regarding the seven studies that examined the effectiveness of the LSB interventions, two multiple baseline designs and five (preliminary) (randomized) controlled trial designs were used. Four of these studies compared the LSB intervention to care as usual or no treatment. Of those four, one study compared a LSB with both a no intervention and a rummage box condition (Crook et al., 2016) and another had the following three conditions: (1) life review work carried out separately - but simultaneously - with the person with dementia and the caregiver; (2) life review carried out with the caregiver alone; and (3) an untreated control group (Haight et al., 2003). The fifth controlled trial study compared a co-creation of a LSB with receiving a LSB as a gift (Subramaniam et al., 2014). Participants were randomly assigned to the conditions, except for the Haight et al., 2003 study, for which it remains unclear whether allocation was random.

\section{Sample size}

The sample sizes ranged from 1 (the case studies) to 56 (multiple case study; Kwak et al., 2018). For the controlled trials, the average sample size was 20 (with a range from 5 to 31 ). In four studies, only the persons with dementia were involved in the study, in nine studies informal caregivers, formal caregivers, or other staff were part of the study, and in one study, it was unclear.

\section{Instruments/Outcome variables}

A large number of different instruments or outcome variables were used. A distinction can be made between qualitative and quantitative measurements. To explore the implementation process of the interventions, qualitative instruments, such as (semi-structured) interviews, observations, open questions, conversations, and field notes, were used. To assess the effectiveness of the interventions, multiple questionnaires and observational instruments were used on different stakeholders. Participant-focused outcomes were, e.g. autobiographical memory, depression, and quality of life. Furthermore, questionnaires on the quality of the caregiving relationship and communication between the informal caregiver and person with dementia were assessed. Informal caregiver measures were on caregiver burden and formal caregiver measures were on knowledge and attitudes. The outcome measures in the controlled trial studies were applied on baseline as well as during the intervention (Crook et al., 2016) or after the intervention with a maximum of 18 weeks (Subramaniam et al., 2014).

\section{Findings}

QUALITATIVE FINDINGS

All those involved looked back on the interventions as an enjoyable process and they viewed a LSB as a useful tool triggering memories and - largely positive - emotions. Participants, relatives, and care staff saw the value of the LSB mainly in improvements in relationships: partner affirmation, engagement, fullness of life as a couple, social interaction, and communication. Furthermore, several (cultural) themes were identified and recommendations for implementing a LSB intervention were given, e.g. 


\begin{tabular}{|c|c|c|c|}
\hline AUTHOR & AIM OF STUDY & TYPE OF STUDY & $\begin{array}{l}\text { SAMPLE } \\
\text { SIZE }\end{array}$ \\
\hline Kwak et al. (2018) & $\begin{array}{l}\text { Adaptation of "couples life story approach" in South } \\
\text { Korea }\end{array}$ & Multiple qualitative case study design & 56 \\
\hline $\begin{array}{l}\text { Subramaniam and } \\
\text { Woods (2016) }\end{array}$ & Acceptability and efficacy & $\begin{array}{l}\text { Multiple baseline design } \\
\text { Qualitative study }\end{array}$ & 6 \\
\hline $\begin{array}{l}\text { Ingersoll-Dayton et al. } \\
\quad(2016)\end{array}$ & Development of "couples life story approach" & Qualitative study & 29 \\
\hline Crook et al. (2016) & Initial evidence on well-/ill-being and behavior & $\begin{array}{l}\text { Randomized multiple baseline design with three } \\
\text { conditions: } \\
\text { 1) life story book } \\
\text { 2) rummage box } \\
\text { 3) no-intervention condition }\end{array}$ & 5 \\
\hline Hashim et al. (2015) & $\begin{array}{l}\text { Evidence on management of everyday tasks, reminiscence, } \\
\text { and cognitive function }\end{array}$ & Qualitative case study & 1 \\
\hline $\begin{array}{l}\text { Subramaniam et al. } \\
\quad(2014)\end{array}$ & $\begin{array}{l}\text { Effect of different pathways for developing a life story } \\
\text { book }\end{array}$ & $\begin{array}{l}\text { Preliminary RCT with two conditions: } \\
\text { 1) receiving } 12 \text { individual life review sessions and } \\
\text { co-creating a LSB } \\
\text { 2) receiving a personal LSB created by their relatives as a } \\
\text { "gift" } \\
\text { Two case study vignettes }\end{array}$ & $\begin{array}{l}23 \\
11 \\
12\end{array}$ \\
\hline Scherrer et al. (2014) & $\begin{array}{l}\text { Mapping challenges of conducting narrative-based } \\
\text { interventions }\end{array}$ & Multiple baseline single case design & 20 \\
\hline Hashim et al. (2013) & $\begin{array}{l}\text { Developing a digital memory book application to the need } \\
\text { of the patient }\end{array}$ & Qualitative case study & 1 \\
\hline $\begin{array}{l}\text { Ingersoll-Dayton et al. } \\
\quad(2013)\end{array}$ & $\begin{array}{l}\text { To help individuals who have dementia and their spouses } \\
\text { or partners communicate and reminisce about their life } \\
\text { and develop a book that incorporates mementoes of } \\
\text { their life }\end{array}$ & Qualitative study & 24 \\
\hline McKeown et al. (2013) & $\begin{array}{l}\text { To understand experiences of people with dementia, } \\
\text { family carers, and care staff in using life story work and } \\
\text { to explore the process taken for life story work to be } \\
\text { implemented }\end{array}$ & Multiple baseline design & 4 \\
\hline $\begin{array}{l}\text { Morgan and Woods } \\
\quad(2010)\end{array}$ & $\begin{array}{l}\text { To gain empirical evidence on the impact of life review } \\
\text { therapy with people with dementia }\end{array}$ & $\begin{array}{l}\text { Preliminary RCT with two conditions: } \\
\text { 1) life review which culminated in the creation of a LSB } \\
\text { 2) treatment as usual } \\
\text { Two case study vignettes }\end{array}$ & $\begin{array}{l}17 \\
8 \\
9\end{array}$ \\
\hline Haight et al. (2006) & $\begin{array}{l}\text { To test the effectiveness of a structured life review/life } \\
\text { storybook process }\end{array}$ & $\begin{array}{l}\text { Controlled pilot RCT with two conditions: } \\
\text { 1) life review/life storybook } \\
\text { 2) care as usual }\end{array}$ & $\begin{array}{l}31 \\
15 \\
16\end{array}$ \\
\hline
\end{tabular}


Table 3. Continued

\begin{tabular}{|c|c|c|c|}
\hline AUTHOR & AIM OF STUDY & TYPE OF STUDY & $\begin{array}{l}\text { SAMPLE } \\
\text { SIZE }\end{array}$ \\
\hline $\begin{array}{l}\text { Andrews-Salvia et al. } \\
\text { (2003) }\end{array}$ & $\begin{array}{l}\text { To assess the effect of memory books } \\
\text { on the number of on-topic facts } \\
\text { stated for three topics (life, family, } \\
\text { and day) }\end{array}$ & Multiple baseline design & 4 \\
\hline Haight et al. (2003) & $\begin{array}{l}\text { Reviewing the application of } \\
\text { reminiscence with people with } \\
\text { dementia }\end{array}$ & $\begin{array}{l}\text { Study with three conditions: } \\
\text { 1) life review work carried out } \\
\text { separately - but simultaneously - } \\
\text { with the person with dementia and } \\
\text { the caregiver } \\
\text { 2) life review carried out with the } \\
\text { caregiver alone } \\
\text { 3) an untreated control group } \\
\text { Two case study vignettes }\end{array}$ & $\begin{array}{l}22 \\
- \\
- \\
-\end{array}$ \\
\hline
\end{tabular}

Note: - = missing data

on how to incorporate difficult life events in the LSB, how to tell a mutual story, and how to end the story. No negative effects were reported.

\section{Quantitative efFects}

In the five controlled trial studies, the LSB interventions showed significant improvements in autobiographical memory, mood, depression, and quality of life of the persons with dementia compared with care as usual or no treatment. Furthermore, the communication and quality of relationships between participants and their informal caregivers improved significantly. Finally, significant improvement on staff attitudes and knowledge was found. In one study, two reminiscence intervention conditions (one being a LSB intervention and the other a rummage box) showed significant improvement compared to the no intervention condition, but no difference was found between the LSB condition and the rummage box condition (Crook et al., 2016). Moreover, some positive non-significant changes in independence and behavior problems in favor of the LSB intervention were reported (Haight et al., 2006). One study reported a mixed outcome: the persons with dementia in the dyadic LSB condition showed a significant decrease in cognition compared to the caregiver only and no treatment condition, while mood and burden improved in both the dyadic and caregiver only condition (Haight et al., 2003).

\section{Discussion}

Reminiscence can be used to enhance PCC and has proven to be effective for persons with dementia (Woods et al., 2005; Subramaniam and Woods, 2012; Blake, 2013; Huang et al., 2015).
The creation of a LSB is a specific form of reminiscence that is the result of a life review process that illustrates the biography of a person. This systematic review of 14 studies showed that most LSBs were tangible books that were created in about six individual sessions in nursing homes with persons with varying degrees of dementia as well as with their informal and formal caregivers. Process evaluations showed the value of LSBs in triggering memories and positive emotions and in improving the relation with the person with dementia. Quantitative evaluations supported this value as significant improvements were found on autobiographical memory, depression, mood, and quality of life of the persons with dementia, as well as on the quality of relationships and communication between the person with dementia and the informal caregiver. Furthermore, effects on burden of the informal caregivers and on attitudes and knowledge of formal caregivers were found in comparison to care as usual.

The findings for persons with dementia are in line with earlier reviews and a meta-analysis that have shown that reminiscence activities can contribute to cognitive functioning, depression, and quality of life of persons with dementia (Woods et al., 2005; Subramaniam and Woods, 2012; Blake, 2013; Huang et al., 2015). The findings for caregivers and their relation to persons with dementia indicate that LSBs can contribute to the culture change towards more PCC (Koren, 2010; AGS, 2016; Higgs and Gilleard, 2017). The relationship between persons with dementia and their formal and informal caregivers appears to be improved and the expression of values and preferences of persons with dementia in LSBs can further contribute to support their health and life goals. This also aligns with previous findings that 
Table 4. Overview of instruments and findings

AUTHOR

INSTRUMENTS/OUTCOME VARIABLES

Kwak et al. (2018)

Primary data: session notes written by interventionists. Supplementary data: interviews with participants and weekly team meeting notes

Subramaniam and Woods (2016)

Ingersoll-Dayton et al. (2016)

Crook et al. (2016)

Subramaniam et al. (2014)

Scherrer et al. (2014)
Quantitative: Quality of life-Alzheimer's disease scale (QOL-AD), autobiographical memory interview extended version (AMI-E; subscales PSS and AIS); Geriatric Depression Scale Residential (GDS-12R); quality of the caregiving relationship questionnaire (QCPR).

Qualitative: Open-ended questions.

Clinical analysis of the progress of the couples discussed by members of the Japanese and American teams. Based on these discussions, four themes emerged that characterized how the couples experienced this intervention

Dementia care mapping (DCM), divided into behavior category code (BCC), and mood-engagement value (ME), calculated into well-/ill-being (WIB). The questionnaires were filled out on two days before baseline and on nine consecutive days during the intervention conditions

An evaluation form that contains a set of questions related to presentation, motivation, understanding, memorability, learnability, and usability

Quality of life-Alzheimer's disease (QOL-AD); autobiographical memory interview extended version (AMI-E); The Geriatric Depression Scale (Residential) (GDS-12R); quality of the caregiving relationship questionnaire (QCPR participant and relative); approaches to dementia questionnaire (ADQ); staff knowledge of care-recipient questionnaire. The questionnaires were filled out on baseline and on follow-up at 12 and 18 weeks

Description of two cases

During team meetings, social workers described the positive changes that they observed in their weekly meetings with couples, as well as the challenges they encountered. These challenges were discussed as the project leaders and other members of the project team considered strategies to address them
Cultural themes identified: (1) dealing with negative memories in early years of marriage; (2) communication styles and patterns; (3) ways to incorporate difficult life events into the life story book; and (4) complex dynamics of hierarchy in the relationship between older couples and the interventionist

Digital LSB > LSB. Positive average improvement on quality of life, autobiographical memory (subscale PSS), depression, and quality of caregiving relationship

Those involved viewed digital life story books as a very useful tool stimulating memories, triggering positive emotions, and encouraging conversation and interaction

Themes found: partner affirmation (highlighting each other's strengths), improved engagement; handling losses; and fullness of a life as a couple

Reminiscence conditions $>$ no intervention condition. Higher WIB, but not consistent across all participants. Both

reminiscence conditions tended to be associated with an increase in communicative, expressive, and intellectual behaviors. No significant difference was found between the LSB and rummage box

Positive feedback and user satisfaction. Patient felt motivated and enjoyed using the application that supported managing her daily activities, reminiscence, and cognitive function

Both LSB conditions (co-creation and gift) show significant improvements on quality of life $(p=0.035)$ and autobiographical memory $(p=0.001-0.005)$ at post-intervention, and on quality of relationship at six-week follow-up $(p=0.046)$. Staff attitude $(p<0.001)$ and knowledge $(p<0.001)$ was improved at six-week follow-up. No difference was found between the two LSB conditions

The book appeared to play a role as a maintenance tool after the completion of the life review process and helped the participants to look back on their life

Recommendations are given on how to (1) construct a narrative from disparate stories, (2) tell a mutual story, (3) tell the story of a couple that has been in a shorter relationship, (4) incorporate others in the story, (5) include difficult life moments, and (6) end the story 
Table 4. Continued

\begin{tabular}{|c|c|c|}
\hline AUTHOR & INSTRUMENTS/OUTCOME VARIABLES & FINDINGS \\
\hline Hashim et al. (2013) & $\begin{array}{l}\text { Interviews with caretaker and doctor to assess needs; observation of } \\
\text { behavior during sessions; testing of long- and short-term memory } \\
\text { (unclear how) }\end{array}$ & $\begin{array}{l}\text { The results show that by using the application, not only the } \\
\text { patient's reminiscence is improved regarding to performing prayer } \\
\text { (short term memory), but it also upgrades the social interaction } \\
\text { and communication between the patient and caretaker }\end{array}$ \\
\hline $\begin{array}{l}\text { Ingersoll-Dayton } \\
\quad \text { et al. (2013) }\end{array}$ & $\begin{array}{l}\text { Questionnaires with open-ended questions about their reactions to } \\
\text { the approach (participants and caregivers) and observations }\end{array}$ & $\begin{array}{l}\text { Positive aspects mentioned by participants are as follows: enjoyed } \\
\text { reliving story of life together; communication tips were useful; } \\
\text { enjoyed the life story book; planned to share the life story book } \\
\text { with others; meaningful engagement; and helped memory }\end{array}$ \\
\hline $\begin{array}{l}\text { McKeown et al. } \\
\quad(2013)\end{array}$ & $\begin{array}{l}\text { Semi-structured interviews, observation, conversations, and field } \\
\text { notes }\end{array}$ & $\begin{array}{l}\text { Private memories were sometimes recalled by the person with } \\
\text { dementia that were not for inclusion in any written product; } \\
\text { enabling the person with dementia to tell their own life story } \\
\text { could be a challenge; quality of the life story books was variable; } \\
\text { and, at times, life story work may be overused with the person } \\
\text { with dementia }\end{array}$ \\
\hline \multirow[t]{2}{*}{$\begin{array}{l}\text { Morgan and Woods } \\
\quad(2010)\end{array}$} & $\begin{array}{l}\text { Geriatric Depression Scale-Short Form (GDS-SF); } \\
\text { autobiographical memory interview (AMI). The questionnaires } \\
\text { were filled out on baseline and on follow-up at six weeks }\end{array}$ & $\begin{array}{l}\text { LSB }>\text { treatment as usual. Significant improvement on depression } \\
(p=0.009) \text { and autobiographical memory }(p=0.016) \text { during } \\
\text { follow-up }\end{array}$ \\
\hline & Descriptions of two cases & $\begin{array}{l}\text { Although the life review process and creation of the LSB was } \\
\text { difficult, the participants enjoyed it }\end{array}$ \\
\hline Haight et al. (2006) & $\begin{array}{l}\text { Mini Mental Status Exam (MMSE); Cornell Scale for Depression } \\
\text { (CSDD); Alzheimer's Mood Scale N \& P (neg. and pos.); } \\
\text { functional independence measure (FIM); Communication } \\
\text { Observation Scale for Cognitively Impaired (CS); memory and } \\
\text { behavior problems checklist (MBS). The questionnaires were } \\
\text { filled out one week before and one week after the intervention (of } \\
\text { six weeks) }\end{array}$ & $\begin{array}{l}\text { LSB }>\text { care as usual. Significant improvement on cognitive } \\
\text { functioning }(p<0.0005) \text {, depression }(p<0.015) \text {, positive mood } \\
(p<0.008) \text {, and communication }(p<0.005) \text {. Improvement (not } \\
\text { significant) on independence and memory and behavior problems }\end{array}$ \\
\hline $\begin{array}{l}\text { Andrews-Salvia et al. } \\
\text { (2003) }\end{array}$ & $\begin{array}{l}\text { Number of on-topic facts made by the subjects during conversation } \\
\text { with the experimenters using the memory books as memory aids }\end{array}$ & $\begin{array}{l}\text { All subjects stated more on-topic facts using the memory books } \\
\text { than during the baseline condition }\end{array}$ \\
\hline \multirow[t]{2}{*}{ Haight et al. (2003) } & $\begin{array}{l}\text { Mini-Mental State Exam (MMSE); Alzheimer Mood Scale } \\
\text { (extracted from transcribed interviews); revised memory and } \\
\text { behavior problem checklist; burden interview. The questionnaires } \\
\text { were filled out on baseline and on follow-up at two months }\end{array}$ & $\begin{array}{l}\text { Dyadic }<\text { caregiver only \& no treatment. Significant decrease on } \\
\text { cognition }(p<0.03) . \text { Dyadic }>\text { caregiver only \& no treatment. } \\
\text { Significant improvement on mood }(p<0.04) . \text { Dyadic } \& \\
\text { caregiver only }>\text { no treatment. Significant increased burden } \\
(p<0.06) \text { and behavior problems }(p<0.05) \text { in no treatment }\end{array}$ \\
\hline & Descriptions of two cases & The case studies helped to elucidate the process \\
\hline
\end{tabular}


reminiscence has the potential to enable care staff to see the person behind the patient and enable the patient's voice to be heard, verbally and nonverbally (Woods et al., 2005).

According to the framework for trials of complex interventions created by the Medical Research Council (MRC, 2000), the research on LSBs is ranged between the phase of modelling and the phase of exploratory trails (phase I and phase II). The use of LSBs and the qualitative studies provides insight in the components and underlying mechanisms of LSBs (phase I). The main mechanism is the recollection and sharing of autobiographical memories. The components are an individual or dyadic life review that results in a tangible (digital) life story. The quantitative studies in this review apply to the exploratory trial phase (phase II). In this phase, the components are tested in different designs. Small sample sizes and nonrandom allocation of participants are characteristic for this phase. Despite the fact that the majority of the controlled trials in this review were randomized, we need to interpret the significant improvements found on several outcomes in this review with caution, especially due to the small sample sizes.

The next phase (phase III) would be to conduct larger randomized controlled trial (RCT) studies to establish the effects of LSBs on people with dementia. This phase asks for a good choice of intervention characteristics in relation to outcome measures. Given the diversity in aims and methods of the included interventions, it is hard to state one as the best practice at this moment in time. Hence, when conducting a larger trial, a clear formulation of the aims of the LSB intervention and how the specific components contribute to the aims is necessary.

Overall, the research in the field of the use of LSBs in dementia care is in the first phases of providing evidence. However, one has to realize that research on LSBs in dementia care is a fairly new area of interest, hence the lack of good, solid RCTs with large sample sizes. Given the current state, the small RCTs, pilot studies, and qualitative case studies of this review do provide insights and help future research.

This review shows that an intervention may focus more on the person with dementia and try to improve autobiographical memory, mood, depression, and/or quality of life or, alternatively, focus more on the relationships of (in)formal caregivers with the person with dementia. The process of creating a LSB may be different for both purposes, for example, in terms of the persons who are involved in the process, or in the use of individual forms like Haights LREF (Haight, 1992) versus a dyadic approach like the couples life story approach (Ingersoll-Dayton et al., 2013). Technology might contribute to the first aim due to multimedia effects like music or movies that may more strongly involve the person with dementia in the process of recollecting memories and improving mood. Technology might contribute in another way to the second aim as different persons can contribute to the creation and use of digital LSBs more easily, also making the LSB more interactive. Is it only after conducting good trials that the last phase (phase IV) of long-term implementation can be realized?

This review is the first to provide an overview on the use of LSBs as a specific domain within the field of reminiscence in dementia care. The studies included were diverse in their aims and consequently in their methods, which makes it difficult to compare the studies in a consistent way. However, the diversity does show that creating LSBs needs to be a tailored process. Especially in a time when the need for more PCC is greater than ever, one could question whether there is one golden standard since it always will be a personal, individualized process to create one's life story. Nevertheless, it is worthwhile to investigate the effect of personalized LSBs on larger studies.

Since 12 of the 14 included studies were identified through database searching, it is assumed that the constructed search strategy was sufficient and all relevant studies were identified. The majority of studies in this review report on positive findings or effects, although some studies do mention less positive outcomes. Failed attempts on studies on LSBs may not have been published. This systematic review shows indications of effects of creating LSBs and possible ways to implement LSBs in dementia care, but information on their actual use after the creating process and long-term effects after implementation is lacking.

This systematic review shows that research on LSB interventions for people with dementia is emerging and confirms that the use of LSBs to support reminiscence and PCC is promising.

\section{Conflict of interest}

None.

\section{Description of authors' roles}

T. Elfrink and G. Westerhof formulated the research questions and were the data extractors of this review. T. Elfrink analyzed the data and wrote the article with supervision and feedback from G. Westerhof, M. Kunz, and S. Zuidema. All authors provided comments and read and approved the final manuscript. 


\section{Acknowledgments}

This research was supported by a grant from ZonMw, Alzheimer Nederland, \& PGGM. Contract grant number: 733050610 .

\section{References}

\section{American Geriatrics Society Expert Panel on} Person-Centered Care (AGS). (2016). Person-centered care: a definition and essential elements. Fournal of the American Geriatrics Society, 64, 15-18. doi: 10.1111 /jgs. 13866.

Andrews-Salvia, M., Roy, N. and Cameron, R. M. (2003). Evaluating the effects of memory books. Fournal of Medical, Speech-Language Pathology, 11, 51-59.

Blake, M. (2013). Group reminiscence therapy for adults with dementia: a review. British fournal of Community Nursing, 18, 228-233. doi: 10.12968/bjen.2013.18.5.228.

Clarke, A. (2000). Using biography to enhance the nursing care of older people. British fournal of Nursing, 9, 429-433. doi: 10.12968/bjon.2000.9.7.6323.

Clarke, A., Jane Hanson, E. and Ross, H. (2003). Seeing the person behind the patient: enhancing the care of older people using a biographical approach. fournal of Clinical Nursing, 12, 697-706. doi: 10.1046/j.1365-2702.2003.00784.

Conde-Sala, J. L. et al. (2016). Effects of anosognosia and neuropsychiatric symptoms on the quality of life of patients with Alzheimer's disease: a 24-month follow-up study. International fournal of Geriatric Psychiatry, 31, 109-119. doi: 10.1002/gps.4298.

Crook, N., Adams, M., Shorten, N. and Langdon, P. E. (2016). Does the well-being of individuals with Down syndrome and dementia improve when using life story books and rummage boxes? a randomized single case series experiment. Fournal of Applied Research in Intellectual Disabilities, 29, 1-10. doi: 10.1111/jar.12151.

De Vugt, M. E. et al. (2003). Behavioural disturbances in dementia patients and quality of the marital relationship. International fournal of Geriatric Psychiatry, 18, 149-154. doi: $10.1002 /$ gps.807.

Haight, B. K. (1992). The structured life-review process: a community approach to the ageing client. In G. M. M. Jones and B. M. L. Miesen (eds.), Care-Giving in Dementia (pp. 272-292). London: Routledge.

Haight, B. K., Bachman, D. L., Hendrix, S., Wagner, M. T., Meeks, A. and Johnson, J. (2003). Life review: treating the dyadic family unit with dementia. Clinical Psychology \& Psychotherapy, 10, 165-174. doi: 10.1002/cpp.367.

Haight, B. K., Gibson, F., and Michel, Y. (2006). The Northern Ireland life review/life storybook project for people with dementia. Alzheimer's E Dementia, 2, 56-58. doi: $10.1016 /$ j.jalz.2005.12.003.

Hashim, A. H. A., Ismail, A. N., Rias, R. M. and Mohamed, A. (2015). The development of an individualized digital memory book for Alzheimer's disease patient: a case study. In International Symposium Technology Management and Emerging Technologies (ISTMET), 2015 (pp. 227-232). Langkawi Island, Malaysia: IEEE. doi: 10.1109/ISTMET.2015.7359034.

Hashim, A. H. A., Rias, R. M. and Kamaruzaman, M. F. (2013). The use of personalized digital memory book as a reminiscence therapy for Alzheimer's disease (AD) patients. In H. B. Zaman, P. Robinson, P. Olivier, T. K. Shih, and S. Velastin (eds.), International Visual Informatics Conference (pp. 508-515). New York: Springer-Verlag. doi: 10.1007/978-3-319-02958-0_46.

Higgs, P. and Gilleard, C. (2017). Ageing, dementia and the social mind: past, present. Sociology of Health E Illness, 39, 175-181. doi: 10.1111/1467-9566.12536.

Huang, H. C. et al. (2015). Reminiscence therapy improves cognitive functions and reduces depressive symptoms in elderly people with dementia: a meta-analysis of randomized controlled trials. Fournal of the American Medical Directors Association, 16, 1087-1094. doi: 10.1016/j.jamda.2015.07.010.

Ingersoll-Dayton, B., Spencer, B., Campbell, R., Kurokowa, Y. and Ito, M. (2016). Creating a duet: the couples life story approach in the United States and Japan. Dementia, 15, 481-493. doi: $10.1177 / 1471301214526726$.

Ingersoll-Dayton, B., Spencer, B., Kwak, M., Scherrer, K., Allen, R. S. and Campbell, R. (2013). The couples life story approach: a dyadic intervention for dementia. Fournal of Gerontological Social Work, 56, 237-254. doi: 10.1080/01634372.2012.758214.

Koren, M. J. (2010). Person-centered care for nursing home residents: the culture-change movement. Health Affairs, 29, 312-317. doi: 10.1377/hlthaff.2009.0966.

Kwak, M., Ha, J. H., Hwang, S. Y., Ingersoll-Dayton, B. and Spencer, B. (2018). Cultural adaptation of a dyadic intervention for Korean couples coping with Alzheimer's disease. Clinical Gerontology, 41, 217-226. doi: 10.1080/07317115.2017.1366385.

McHugh, M. L. (2012). Interrater reliability: the kappa statistic. Biochemia Medica, 22, 276-282. doi: 10.11613/BM.2012.031.

McKeith, I. and Cummings, J. (2005). Behavioural changes and psychological symptoms in dementia disorders. The Lancet Neurology, 4, 735-742. doi: 10.1016/S1474-4422(05)70219-2.

McKeown, J., Clarke, A. and Repper, J. (2006). Life story work in health and social care: systematic literature review. Fournal of Advanced Nursing, 55, 237-247. doi: 10.1111/j.1365-2648.2006.03897.x.

McKeown, J., Ryan, T., Ingleton, C. and Clarke, A. (2013). 'You have to be mindful of whose story it is': the challenges of undertaking life story work with people with dementia and their family carers. Dementia, 14, 238-256. doi: $10.1177 / 1471301213495864$.

Medical Research Council. (2000). A Framework for the Development and Evaluation of RCTs for Complex Interventions to Improve Health. London: MRC.

Moher, D. et al. (2015). Preferred reporting items for systematic review and meta-analysis protocols (PRISMA-P) 2015 statement. Systematic Reviews, 4, 1. doi: 10.1186/2046-4053-4-1.

Morgan, S. and Woods, R. T. (2010). Life review with people with dementia in care homes: a preliminary 
randomized controlled trial. Non-pharmacological Therapies in Dementia, 1, 43-60.

Peeters, J. E., Werkman, W. and Francke, A. L. (2012). Dementiemonitor Mantelzorg: Problemen, Zorgbehoeften, Zorggebruik en Oordelen van Mantelzorgers. Utrecht, the Netherlands: Nivel.

Prince, M., Prina, M. and Guerchet, M. (2013). Fourney of Caring. An Analysis of Long-Term Care for Dementia. London: Alzheimer's Disease International.

Prince, M., Wimo, A., Guerchet, M., Ali, G. C., Wu, Y. T. and Prina, A.M. (2015). The Global Impact of Dementia. An Analysis of Prevalence, Incidence, Cost and Trends. London: Alzheimer's Disease International.

Scherrer, K. S., Ingersoll-Dayton, B. and Spencer, B. (2014). Constructing couples' stories: narrative practice insights from a dyadic dementia intervention. Clinical Social Work fournal, 42, 90-100.

Subramaniam, P. and Woods, B. (2012). The impact of individual reminiscence therapy for people with dementia: systematic review. Expert Review of Neurotherapeutics, 12, 545-555. doi: 10.1586/ern.12.35.

Subramaniam, P. and Woods, B. (2016). Digital life storybooks for people with dementia living in care homes: an evaluation. Clinical Interventions in Aging, 11, 1263-1276. doi: 10.2147/CIA.S111097.

Subramaniam, P., Woods, B. and Whitaker, C. (2014). Life review and life story books for people with mild to moderate dementia: a randomised controlled trial. Aging $\mathcal{E}$ Mental Health, 18, 363-375. doi: 10.1080/13607863.2013.837144.

VandenBos, G. R. (eds.) (2006). APA Dictionary of Psychology, 1st edn. Washington, DC: American Psychological Association.

Woods, B., Spector, A., Jones, C., Orrell, M. and Davies, S. (2005). Reminiscence therapy for dementia. Cochrane Database of Systematic Reviews, 2. doi: 10.1002/14651858.CD001120.pub2.

World Health Organization (WHO). (2017). Facts on Dementia. Available at: http://www.who.int/features/ factfiles/dementia/en/; last accessed 9 May 2017. 